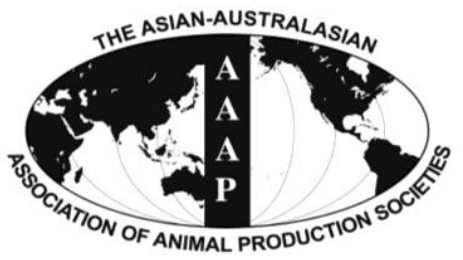

Asian-Aust. J. Anim. Sci.

Vol. 25, No. 9 : 1262 - 1268

September 2012

www.ajas.info

http://dx.doi.org/10.5713/ajas.2012.12043

\title{
Effect of Vitamin E Supplementation on Hematological and Plasma Biochemical Parameters during Long Term Exposure of Arsenic in Goats
}

\author{
Tapan Kumar Das, Veena Mani*, Harjit Kaur, Neelam Kewalramani and Anjali Agarwal \\ Dairy Cattle Nutrition Division, National Dairy Research Institute, Karnal, Haryana-132001, India
}

\begin{abstract}
The present investigation was designed to determine whether supplementation of different level of vitamin E for 12 months to arsenic exposed goats (50 ppm as sodium arsenite) affords protection against the blood hemato-biochemical parameters caused by the metalloid. A total of 24 crossbred (Alpine $\times$ Beetal) lactating goats were assigned randomly into 4 equal groups (control, $\mathrm{T}_{1}$, $\mathrm{T}_{2}$ and $\left.\mathrm{T}_{3}\right)$ of 6 in each, on the basis of average body weight $(36.10 \pm 0.11 \mathrm{~kg})$ and milk yield $(1.61 \pm 0.04 \mathrm{~kg} / \mathrm{d}) . \mathrm{The}$ animals in $\mathrm{T}_{1}, \mathrm{~T}_{2}$ and $\mathrm{T}_{3}$ were given $50 \mathrm{ppm}$ arsenic, while in $\mathrm{T}_{2}$ and $\mathrm{T}_{3}$, additionally; vitamin $\mathrm{E}$ at the rate of $100 \mathrm{IU}$ and $150 \mathrm{IU} / \mathrm{kg}$ dry matter (DM) respectively was additionally supplemented for the period of 12 months. Hemoglobin (Hb), total leukocyte (TLC) and blood lymphocyte \% were decreased $(\mathrm{p}<0.05)$ in arsenic fed groups and vitamin E supplementation in the experimental group showed a protective potential. Significant increases $(\mathrm{p}<0.05)$ in aspertate transaminase (AST) and alanine transaminase (ALT) activities among arsenic supplemented groups were recorded, however vitamin E supplementation at higher doses showed a protective effect $(p<0.05)$ against AST but in the case of ALT no ameliorating effect was found in either of the doses. Plasma total protein was decreased ( $p>0.05$ ) but creatinine level was periodically increased in all As supplemented groups and vitamin E supplementation did not produce any protective effect. It can be concluded that arsenic exposure resulted in varying degree of changes in hemato-biochemical parameters and activities of antioxidant enzymes in goats but concomitant treatment with Vitamin E is partially helpful in reducing the burden of arsenic induced effect. (Key Words: Arsenic, Biochemical Parameter, Goat, Hemoglobin, Vitamin E, Total Protein)
\end{abstract}

\section{INTRODUCTION}

Arsenic (As) is a metalloid found in water, soil, and air from natural and anthropogenic sources (Hughes, 2002). Arsenic occurs in both organic and inorganic forms in nature, but the inorganic form is more toxic and represents a potential threat to the environment, human health, and animal health. Various livestock animals are also the likely victims of such catastrophes arising from As pollution due to contamination of drinking water. Administration of As could affect animal performances and serum clinical parameters. Liver and kidneys are considered as the primary targets for its toxico-pathological manifestations and there are a few reports of biochemical alterations indicative of hepatic and renal system involvement in As toxicity in animals (Biswas et al., 1998; Santra et al., 1999; Nandi et al., 2005). However, little data have been reported in

\footnotetext{
* Corresponding Author: Veena Mani. Tel: +911842272516, Fax: +911842250042, E-mail: veenamania@gmail.com Submitted Jan. 5, 2012; Accepted Mar. 23, 2012; Revised Mar. 30, 2012
}

lactating dairy animals. For cattle, sheep and swine maximum tolerable dietary As recommended is $50 \mathrm{~g} / \mathrm{kg}$ (inorganic) and $100 \mathrm{mg} / \mathrm{kg}$ (organic). The purpose of this study was to evaluate the cumulative effect of recommended inorganic As in a long term exposure in lactating goats. In rat model, beneficial role of antioxidants have been reported earlier against As toxicity (Ramanathan et al., 2002; Nandi et al., 2006). Beneficial role of feeding ascorbic acid as an antioxidant has been reported in rabbit (Rabbani et al., 2003), rat (Nandi et al., 2006) and in rodents (Rana et al., 2010). Likely, vitamin E is a dietary essential which act as first line of defence in ruminants against pro-oxidant. As the vitamin $\mathrm{E}$ requirement of all classes goat is $100 \mathrm{IU} / \mathrm{kg}$ (Morand-Fehr, 1981), therefore 100 and $150 \mathrm{IU} / \mathrm{kg}$ doses are decided to evaluate the antioxidant effect. Taking into consideration of the above facts, the present investigation was undertaken to assess the protective effect of vitamin $\mathrm{E}$ at two levels against As induced changes in hematological and plasma biochemical variables indicative of hepatic and renal functions in lactating goats. 


\section{MATERIALS AND METHODS}

\section{Experimental design and treatments}

A total of 24 crossbred lactating goats (2nd to 3rd stage of lactation) were selected from the Cattle Yard of National Dairy Research Institute, Karnal, India and distributed randomly into 4 groups of 6 each. The distribution of the animals was done on the basis of average milk yield $(1.61 \pm 0.04 \mathrm{~kg} / \mathrm{d})$ and body weight $(36.10 \pm 0.11 \mathrm{~kg})$. The experimental feeding period was of 12 months. The details of the treatments are as follows:

Group I (C): Control animals

Group II $\left(\mathrm{T}_{1}\right)$ : Arsenic as sodium arsenite, $50 \mathrm{mg} / \mathrm{kg}$ dry matter (DM)

Group III $\left(\mathrm{T}_{2}\right)$ : Arsenic as in group II plus vitamin E, $100 \mathrm{IU} / \mathrm{kg} \mathrm{DM}$

Group III $\left(\mathrm{T}_{3}\right)$ : Arsenic as in group II plus vitamin $\mathrm{E}$, $150 \mathrm{IU} / \mathrm{kg} \mathrm{DM}$

\section{Diets and feeding}

The goats were housed in well ventilated pens having facilities for individual feeding. Deworming schedule was followed at the beginning of the experiment and thereafter, at six month interval. The experiment was performed with approval from Institute (NDRI, India) Animal Ethics Committee (IAEC No. 28/09-21/11/2009). Before the trial, animals were adapted to the new environment and fed As and vitamin $\mathrm{E}$ capsule for 7 days. The animals were fed as per NRC (1981) feeding standard to meet their nutrient requirements. The concentrate mixture was offered in the morning in the plastic tubs whereas, the chaffed green fodder was offered at 11:00 AM. As it was a long term study, two types of fodder either berseem or maize depending upon the season/availability was provided. Concentrate mixture (maize $33 \%$, groundnut cake (oiled) $21 \%$, mustard oil cake (oiled) $12 \%$, wheat bran $20 \%$, deoiled rice bran $11 \%$, mineral mixture $2 \%$ and common salt $1 \%$ ) having $\mathrm{CP}$ $19.81 \%$ and TDN 70\% was procured from Godrej Agrovet Pvt Ltd. Composition of roughage and concentrate mixture was estimated by drawing weekly samples and every effort was made to maintain the supply of the given fodder of similar composition. Content of As in concentrate mixture, berseem and maize were $1.116,0.10$ and $0.09 \mathrm{mg} / \mathrm{kg}$ and content of vitamin E were 10.72, 24.86 and $5.99 \mathrm{mg} / \mathrm{kg}$ respectively. $50 \mathrm{mg}$ elemental As/ $/ \mathrm{kg}$ dietary DM as sodium arsenite (s-d-Fine-Chem Limited, India, purity 98.5\%) and 100 and $150 \mathrm{IU}$ vitamin E/kg dietary DM as dl- $\alpha$ tocopheryl acetate (Lutavit, BASF, Germany, minimum assay 50\%) was weighed, packed in gelatine capsules. Arsenic containing capsules were administered orally to each goat of $T_{1}, T_{2}$ and $T_{3}$ groups whereas vitamin $E$ capsules of $100 \mathrm{IU}$ and $150 \mathrm{IU}$ doses were given to each goat of $T_{2}$ and $T_{3}$ groups, respectively. The concentration of
As was also determined in the water that the animals drank and was found to be $0.003 \mathrm{mg} / \mathrm{L}$. Proximate analysis (DM, $\mathrm{CP}, \mathrm{EE}, \mathrm{CF}, \mathrm{NFE}$ and ash) of concentrate mixture, green fodder (berseem and maize) was performed according to methods described in AOAC (2005).

\section{Collection and processing of blood samples}

Blood samples were collected aseptically from jugular vein of each animal using heparinized vacutainer tube (Becton Dickinson India Pvt. Ltd., New Delhi, India). Immediately after collection, tubes were placed in freeze $\left(4^{\circ} \mathrm{C}\right)$ and analyzed subsequently. Plasma was harvested subsequently by centrifuging the whole blood samples at $840 \mathrm{~g}$ for $15 \mathrm{~min}$ in a portable centrifuge machine (HERMLE Labortechnik GmbH, Germany). The heparinized plasma samples were stored at $-20^{\circ} \mathrm{C}$ in storage vials and analyzed subsequently.

\section{Hematological parameters}

The haemoglobin $(\mathrm{Hb})$ content of blood was estimated by Drabkin cyanomethemoglobin method (Drabkin, 1944). Blood leukocytes (TLC) and lymphocyte \% were done using Neubauer chamber.

\section{Biochemical estimation}

Plasma biochemical parameters: Activity of plasma AST and ALT was estimated following the method of Reitman and Frankel (Reitman and Frankel, 1957) using commercial kit (Span Diagnostics Ltd, Surat, India) and the values were expressed as U/L of plasma. Plasma Total protein was measured using modified Biuret method (Koller, 1984) and values were expressed in gm/dl. Plasma creatinine was measured spectrophotometrically using alkaline picrate method (Bonses and Taussky, 1945).

\section{Statistical analysis}

The data were analyzed using two way repeated measures ANOVA (Sigma Plot software, version 11.0; SPSS Inc., Chicago IL, USA) with two factors i.e., different treatment groups and periods. All results were compared to control animals, as well as to the As exposed animals, in order to elucidate the possible protective effect of vitamin $\mathrm{E}$ supply on As toxicity. Tukey's all pair wise multiple comparison tests have been used to compare means between the different treatment groups. The results were represented as mean $\pm \mathrm{SE}$ in the treatment and period interaction table mentioning the significance level. The specific $\mathrm{p}$ values were mentioned in the text for where there was significant difference found.

\section{RESULTS AND DISCUSSION}

After an initial increase $(p=0.034)$ in $\mathrm{Hb}$ concentration 
Table 1. Effect of vitamin E supplementation on blood $\mathrm{Hb}(\mathrm{gm} \%)$ in As fed goats

\begin{tabular}{|c|c|c|c|c|c|}
\hline \multirow{2}{*}{$\begin{array}{l}\text { Period } \\
\text { (Months) }\end{array}$} & \multicolumn{4}{|c|}{ Treatments } & \multirow{2}{*}{ Mean } \\
\hline & $\mathrm{C}$ & $\mathrm{T}_{1}$ & $\mathrm{~T}_{2}$ & $\mathrm{~T}_{3}$ & \\
\hline 0 & $9.27 \pm 0.12$ & $8.90 \pm 0.23$ & $9.06 \pm 0.14$ & $9.52 \pm 0.18$ & $9.19 \pm 0.13$ \\
\hline 1 & $9.87 \pm 0.36$ & $9.93 \pm 0.38$ & $10.49 \pm 0.45$ & $10.05 \pm 0.27$ & $10.09 \pm 0.14$ \\
\hline 2 & $9.59^{\mathrm{a}} \pm 0.14$ & $10.17^{\mathrm{ab}} \pm 0.29$ & $10.45^{\mathrm{b}} \pm 0.30$ & $10.31^{\mathrm{ab}} \pm 0.25$ & $10.13 \pm 0.19$ \\
\hline 3 & $9.85 \pm 0.35$ & $9.29 \pm 0.11$ & $9.58 \pm 0.18$ & $9.63 \pm 0.23$ & $9.58 \pm 0.12$ \\
\hline 4 & $10.13^{b} \pm 0.05$ & $9.11^{\mathrm{a}} \pm 0.16$ & $9.40^{\mathrm{ab}} \pm 0.15$ & $9.71^{\mathrm{ab}} \pm 0.19$ & $9.59 \pm 0.22$ \\
\hline 5 & $9.80^{\mathrm{b}} \pm 0.23$ & $8.26^{\mathrm{a}} \pm 0.13$ & $9.01^{\mathrm{ab}} \pm 0.23$ & $9.39^{b} \pm 0.16$ & $9.12 \pm 0.33$ \\
\hline 6 & $10.31^{\mathrm{c}} \pm 0.26$ & $8.00^{\mathrm{a}} \pm 0.12$ & $8.81^{\mathrm{ab}} \pm 0.26$ & $8.95^{\mathrm{b}} \pm 0.22$ & $9.01 \pm 0.48$ \\
\hline 7 & $10.15^{\mathrm{c}} \pm 0.33$ & $7.84^{\mathrm{a}} \pm 0.11$ & $8.55^{\mathrm{ab}} \pm 0.16$ & $8.75^{\mathrm{b}} \pm 0.22$ & $8.82 \pm 0.48$ \\
\hline 8 & $9.94^{\mathrm{c}} \pm 0.12$ & $7.41^{\mathrm{a}} \pm 0.12$ & $8.36^{\mathrm{b}} \pm 0.27$ & $8.61^{\mathrm{b}} \pm 0.25$ & $8.58 \pm 0.52$ \\
\hline 9 & $9.78^{c} \pm 0.19$ & $7.12^{\mathrm{a}} \pm 0.20$ & $8.21^{\mathrm{b}} \pm 0.21$ & $8.43^{\mathrm{b}} \pm 0.26$ & $8.38 \pm 0.55$ \\
\hline 10 & $9.45^{c} \pm 0.16$ & $6.74^{\mathrm{a}} \pm 0.19$ & $8.02^{\mathrm{b}} \pm 0.17$ & $8.11^{\mathrm{b}} \pm 0.26$ & $8.08 \pm 0.55$ \\
\hline 11 & $9.46^{c} \pm 0.21$ & $6.45^{\mathrm{a}} \pm 0.18$ & $7.80^{\mathrm{b}} \pm 0.21$ & $7.89^{\mathrm{b}} \pm 0.25$ & $7.90 \pm 0.62$ \\
\hline 12 & $9.42^{c} \pm 0.22$ & $6.40^{\mathrm{a}} \pm 0.12$ & $7.74^{\mathrm{b}} \pm 0.20$ & $7.78^{\mathrm{b}} \pm 0.22$ & $7.83 \pm 0.62$ \\
\hline Mean & $9.77^{\mathrm{c}} \pm 0.09$ & $8.12^{\mathrm{a}} \pm 0.36$ & $8.88^{\mathrm{b}} \pm 0.25$ & $9.01^{\mathrm{b}} \pm 0.23$ & \\
\hline
\end{tabular}

Mean within the row bearing different superscript $(a, b, c)$ are significantly different $(p<0.05)$.

at 2 months in $\mathrm{T}_{2}$, thereafter there was gradual decline in $\mathrm{Hb}$ content, thereby suggesting that As administration had an adverse effect as the period of exposure was increased thus confirming its cumulative potential which might have been reflected in depression of $\mathrm{Hb}$ (Table 1$)$. Treatment $\times$ period interaction $(p<0.001)$ was observed during the study. Both $\mathrm{T}_{2}$ and $\mathrm{T}_{3}$ groups started to show its positive effect in increasing $\mathrm{Hb}$ compared to $\mathrm{T}_{1}$ from 8 th $(\mathrm{p}<0.001)$ and 6th $(\mathrm{p}=0.015)$ months onwards respectively and but statistically there was no difference $(p>0.05)$ between these groups thus it can be concluded that vitamin $\mathrm{E}$ supplementation can alleviate adverse effect on $\mathrm{Hb}$ due to As supplementation. But the final value in $\mathrm{T}_{2}$ and $\mathrm{T}_{3}$ was different $(p<0.001)$ from control, so dose of vitamin $E$ was not sufficient enough to completely mitigate the adverse effect caused by As. It is also evident from the overall mean values of dietary treatment.

In all As supplemented groups showed a periodically declining trend of TLC compared to control thus indicating its adverse effect (Table 2). Group $\mathrm{T}_{1}$ showed its adverse effect $(p=0.005)$ from 7 months whereas $T_{2}$ and $T_{3}$ were effective $(p<0.001)$ in mitigation of adverse effect from 10 months onwards. As the experimental feeding was continued further, the declining trend maintained and the group $T_{1}$ showed maximum reduction at the end of 12 months feeding. From the overall mean values of treatments, it was found that vitamin E supplementation at its higher doses significantly mitigate As induced reduction of blood

Table 2. Effect of vitamin E supplementation on blood total leukocyte count $\left(\times 10^{3} / \mathrm{mm}^{3}\right)$ in As fed goats

\begin{tabular}{|c|c|c|c|c|c|}
\hline \multirow{2}{*}{$\begin{array}{l}\text { Period } \\
\text { (Months) }\end{array}$} & \multicolumn{4}{|c|}{ Treatments } & \multirow{2}{*}{ Mean } \\
\hline & $\mathrm{C}$ & $\mathrm{T}_{1}$ & $\mathrm{~T}_{2}$ & $\mathrm{~T}_{3}$ & \\
\hline 0 & $11.18 \pm 0.43$ & $11.20 \pm 0.70$ & $12.03 \pm 0.13$ & $11.55 \pm 0.69$ & $11.49 \pm 0.20$ \\
\hline 1 & $11.12 \pm 0.46$ & $10.50 \pm 0.52$ & $11.20 \pm 0.31$ & $11.27 \pm 0.27$ & $11.02 \pm 0.18$ \\
\hline 2 & $10.67 \pm 0.73$ & $10.37 \pm 0.58$ & $11.02 \pm 0.33$ & $11.14 \pm 0.15$ & $10.80 \pm 0.18$ \\
\hline 3 & $10.47 \pm 0.38$ & $10.47 \pm .65$ & $10.83 \pm 0.36$ & $10.98 \pm 0.26$ & $10.69 \pm 0.13$ \\
\hline 4 & $10.25 \pm 0.48$ & $10.05 \pm 0.33$ & $10.45 \pm 0.40$ & $10.83 \pm 0.27$ & $10.40 \pm 0.17$ \\
\hline 5 & $10.22 \pm 0.51$ & $9.87 \pm 0.28$ & $10.27 \pm 0.33$ & $10.70 \pm 0.34$ & $10.26 \pm 0.17$ \\
\hline 6 & $10.28 \pm 0.30$ & $9.14 \pm 0.34$ & $9.54 \pm 0.29$ & $10.27 \pm 0.64$ & $9.80 \pm 0.28$ \\
\hline 7 & $10.42^{\mathrm{b}} \pm 0.33$ & $8.60^{\mathrm{a}} \pm 0.29$ & $9.24^{\mathrm{ab}} \pm 0.34$ & $9.66^{\mathrm{ab}} \pm 0.45$ & $9.48 \pm 0.38$ \\
\hline 8 & $10.30^{\mathrm{b}} \pm 0.37$ & $8.20^{\mathrm{a}} \pm 0.30$ & $9.08^{\mathrm{ab}} \pm 0.43$ & $9.54^{\mathrm{ab}} \pm 0.26$ & $9.28 \pm 0.44$ \\
\hline 9 & $10.44^{\mathrm{c}} \pm 0.28$ & $7.39^{\mathrm{a}} \pm 0.31$ & $8.20^{\mathrm{ab}} \pm 0.19$ & $8.92^{\mathrm{b}} \pm .29$ & $8.73 \pm 0.65$ \\
\hline 10 & $10.33^{\mathrm{c}} \pm 0.33$ & $5.88^{\mathrm{a}} \pm 0.32$ & $7.69^{\mathrm{b}} \pm 0.28$ & $8.23^{\mathrm{b}} \pm 0.30$ & $8.03 \pm 0.92$ \\
\hline 11 & $10.23^{\mathrm{c}} \pm 0.34$ & $5.61^{\mathrm{a}} \pm 0.28$ & $7.47^{\mathrm{b}} \pm 0.33$ & $8.16^{\mathrm{b}} \pm 0.36$ & $7.87 \pm 0.95$ \\
\hline 12 & $10.15^{\mathrm{c}} \pm 0.38$ & $4.72^{\mathrm{a}} \pm 0.26$ & $7.14^{\mathrm{b}} \pm 0.28$ & $7.86^{\mathrm{b}} \pm 0.35$ & $7.47 \pm 1.12$ \\
\hline Mean & $10.46^{\mathrm{b}} \pm 0.09$ & $8.61^{\mathrm{a}} \pm 0.59$ & $9.55^{\mathrm{c}} \pm 0.44$ & $9.93^{b c} \pm 0.36$ & \\
\hline
\end{tabular}

Mean within the row bearing different superscript $(a, b, c)$ are significantly different $(\mathrm{p}<0.05)$. 
Table 3. Effect of vitamin E supplementation on AST activity (U/L) in As fed goats

\begin{tabular}{|c|c|c|c|c|c|}
\hline \multirow{2}{*}{$\begin{array}{l}\text { Period } \\
\text { (Months) }\end{array}$} & \multicolumn{4}{|c|}{ Treatments } & \multirow{2}{*}{ Mean } \\
\hline & $\mathrm{C}$ & $\mathrm{T}_{1}$ & $\mathrm{~T}_{2}$ & $\mathrm{~T}_{3}$ & \\
\hline 0 & $94.6 \pm 4.12$ & $87.31 \pm 5.06$ & $90.47 \pm 5.23$ & $92.53 \pm 5.00$ & $91.23 \pm 1.56$ \\
\hline 1 & $98.19 \pm 5.12$ & $95.03 \pm 3.41$ & $92.02 \pm 5.45$ & $93.33 \pm 4.85$ & $94.64 \pm 1.33$ \\
\hline 2 & $93.80 \pm 5.80$ & $102.05 \pm 5.85$ & $98.78 \pm 4.92$ & $96.94 \pm 4.48$ & $97.89 \pm 1.73$ \\
\hline 3 & $106.53 \pm 5.87$ & $125.50 \pm 6.17$ & $117.16 \pm 5.81$ & $110.94 \pm 4.50$ & $115.03 \pm 4.11$ \\
\hline 4 & $102.25^{\mathrm{a}} \pm 6.31$ & $129.07^{\mathrm{b}} \pm 5.42$ & $109.88^{\mathrm{ab}} \pm 5.45$ & $111.30^{\mathrm{ab}} \pm 4.00$ & $113.13 \pm 5.68$ \\
\hline 5 & $105.42^{\mathrm{a}} \pm 5.46$ & $137.89^{\mathrm{b}} \pm 4.34$ & $129.60^{\mathrm{b}} \pm 4.95$ & $119.54^{\mathrm{ab}} \pm 4.80$ & $123.11 \pm 6.99$ \\
\hline 6 & $125.21^{\mathrm{a}} \pm 5.28$ & $145.92^{\mathrm{b}} \pm 4.69$ & $137.73^{\mathrm{ab}} \pm 4.63$ & $128.08^{\mathrm{ab}} \pm 4.84$ & $134.23 \pm 4.73$ \\
\hline 7 & $89.16^{\mathrm{a}} \pm 4.28$ & $133.95^{\mathrm{b}} \pm 5.19$ & $123.89^{\mathrm{b}} \pm 5.08$ & $120.49^{\mathrm{b}} \pm 4.12$ & $116.87 \pm 9.67$ \\
\hline 8 & $100.02^{\mathrm{a}} \pm 5.02$ & $137.49^{\mathrm{b}} \pm 6.56$ & $119.45^{\mathrm{ab}} \pm 6.06$ & $120.49^{\mathrm{b}} \pm 6.05$ & $119.36 \pm 7.66$ \\
\hline 9 & $96.36^{\mathrm{a}} \pm 5.01$ & $150.47^{\mathrm{c}} \pm 5.54$ & $121.82^{\mathrm{b}} \pm 5.86$ & $124.88^{\mathrm{b}} \pm 5.39$ & $123.38 \pm 11.06$ \\
\hline 10 & $98.37^{a} \pm 5.64$ & $162.35^{\mathrm{c}} \pm 5.90$ & $129.32^{\mathrm{b}} \pm 5.58$ & $126.64^{\mathrm{b}} \pm 5.66$ & $129.17 \pm 13.09$ \\
\hline 11 & $95.30^{\mathrm{a}} \pm 4.95$ & $160.18^{\mathrm{c}} \pm 5.02$ & $134.92^{\mathrm{b}} \pm 4.54$ & $126.45^{\mathrm{b}} \pm 5.47$ & $129.21 \pm 13.38$ \\
\hline 12 & $99.02^{\mathrm{a}} \pm 4.86$ & $169.91^{\mathrm{c}} \pm 5.47$ & $138.64^{\mathrm{b}} \pm 6.06$ & $132.46^{\mathrm{b}} \pm 6.94$ & $135.01 \pm 14.53$ \\
\hline Mean & $100.33^{\mathrm{a}} \pm 2.45$ & $133.62^{c} \pm 7.18$ & $118.74^{\mathrm{bc}} \pm 4.58$ & $115.70^{\mathrm{ab}} \pm 3.79$ & \\
\hline
\end{tabular}

Mean within the row bearing different superscript $(a, b, c)$ are significantly different $(\mathrm{p}<0.05)$.

TLC. Treatment $\times$ period interaction $(\mathrm{p}<0.001)$ was found during the experimental period.

The present study revealed that As exposed goats suffered from hematological abnormality and these findings were similar to those reported in cattle selected from As contaminated zone (Pandey et al., 2005; Rana et al., 2010). Similarly, Biswas et al. (1998) and Pandey et al. (2005) recorded decreased level of $\mathrm{Hb}$ and marked leucopenia in experimentally produced As toxicity in goats. Reduction of $\mathrm{Hb}$ and TLC might be due to interference in metabolism, suppression of the granulopoietic activity of bone marrow by residual toxicants (Ianchev, 2001; Rana et al., 2008), increased rate of destruction or reduction in rate of formation of erythrocytes and altered cellular composition of blood leading to anemia, anisocytosis, eosinophilia and leucopenia and also due to impaired absorption of folic acid (Hardman and Limbird, 1996) and disruption of liver biosynthesis of heme (Woods and Fowler, 1986). Regarding vitamin $\mathrm{E}$ effect, decreasing trend of $\mathrm{Hb}$ and TLC was observed in As with vitamin E supplemented animals compared to control but that was not statistically significant. The results were in agreement with findings by Patel et al. (2009) and Vaswani et al. (2010) in growing kids.

Due to experimental feeding AST values were increased at the end of experiment in control, $\mathrm{T}_{1}, \mathrm{~T}_{2}$ and $\mathrm{T}_{3}$ groups, respectively. Results showed that there was periodical increase in plasma AST activities in all the treatment groups as compared to control which remained almost similar (Table 3). Treatment $\times$ period interaction $(\mathrm{p}<0.001)$ was observed during the study. In As supplemented group, increase $(p=0.005)$ in AST activities was found from 4 months onwards. This clearly indicated initiation of adverse effect of As supplementation. Both the vitamin E supplemented groups showed protective effect $(\mathrm{p}<0.01)$ of As from 9 months onwards however between the two doses there was no $(p>0.05)$ difference. Though at the end of experiment AST values in $\mathrm{T}_{2}$ and $\mathrm{T}_{3}$ were lower than those in group $\mathrm{T}_{1}$ but still differed $(\mathrm{p}<0.001)$ as compared to control. From the overall mean values it was found that vitamin E supplementation at its higher doses ameliorate As induced increase in AST activity.

In $T_{1}, T_{2}$ and $T_{3}$ groups, with the increase of duration of exposure there was gradual increase of ALT activities (Table 4). Treatment $\times$ period interaction $(p=0.001)$ was also encountered during the experimental period. $\mathrm{T}_{1}$ groups started showing its adverse effect $(\mathrm{p}=0.024)$ after one month of As supplementation. Up to 8 months activity in $\mathrm{T}_{3}$ was comparable to control. After that in both $\mathrm{T}_{2}$ and $\mathrm{T}_{3}$ groups, activities were increased $(\mathrm{p}<0.001)$ in comparison to control group up to the end of experiment but less than $\mathrm{T}_{1}$. From the overall mean values it was observed that vitamin $\mathrm{E}$ at both the doses was not able to mitigate significantly As induced increase in ALT activities.

In the present investigation, there was an increased activity of AST and ALT in As supplemented animals. As a toxic metal, arsenic undergoes biotransformation in the liver and cause hepatic as well as systemic oxidative stress (Nandi et al., 2006). However, the liver hepatocytes are affected by the As as it binds with the thiol group of enzymes and protein present in the cells thus it disfuctionate the hepatocytes plasma membrane leading to increased AST and ALT activities (Woods and Fowler, 1986). Similar observations have been reported by Pandey et al. (2005), Vaswani et al. (2010) and Patel et al. (2009) in As supplemented goat. Rana et al. (2010) also reported significant elevation $(\mathrm{p}<0.05)$ in plasma ALT $(7.452 \pm 0.10)$ 
Table 4. Effect of vitamin E supplementation on ALT activity (U/L) in As fed goats

\begin{tabular}{|c|c|c|c|c|c|}
\hline \multirow{2}{*}{$\begin{array}{l}\text { Period } \\
\text { (Months) }\end{array}$} & \multicolumn{4}{|c|}{ Treatments } & \multirow{2}{*}{ Mean } \\
\hline & $\mathrm{C}$ & $\mathrm{T}_{1}$ & $\mathrm{~T}_{2}$ & $\mathrm{~T}_{3}$ & \\
\hline 0 & $10.85 \pm 0.56$ & $10.13 \pm 0.42$ & $10.10 \pm 0.76$ & $9.40 \pm 0.42$ & $10.12 \pm 0.30$ \\
\hline 1 & $10.73^{\mathrm{a}} \pm 0.23$ & $15.54^{\mathrm{b}} \pm 0.52$ & $12.04^{\mathrm{ab}} \pm 0.98$ & $11.67^{\mathrm{ab}} \pm 0.47$ & $12.50 \pm 1.05$ \\
\hline 2 & $11.35^{\mathrm{a}} \pm 0.69$ & $16.67^{\mathrm{b}} \pm 0.88$ & $13.80^{\mathrm{ab}} \pm 1.34$ & $12.04^{\mathrm{a}} \pm 0.51$ & $13.47 \pm 1.19$ \\
\hline 3 & $11.65^{\mathrm{a}} \pm 0.47$ & $18.23^{\mathrm{b}} \pm 0.97$ & $14.78^{\mathrm{ab}} \pm 1.88$ & $13.42^{\mathrm{a}} \pm 0.58$ & $14.52 \pm 1.39$ \\
\hline 4 & $11.17^{\mathrm{a}} \pm 0.65$ & $18.55^{\mathrm{b}} \pm 1.02$ & $14.59^{\mathrm{ab}} \pm 1.97$ & $13.61^{\mathrm{a}} \pm 1.00$ & $14.48 \pm 1.53$ \\
\hline 5 & $12.33^{\mathrm{a}} \pm 0.76$ & $19.14^{\mathrm{b}} \pm 1.33$ & $15.26^{\mathrm{ab}} \pm 0.74$ & $14.57^{\mathrm{a}} \pm 0.88$ & $15.32 \pm 1.42$ \\
\hline 6 & $12.16^{\mathrm{a}} \pm 0.59$ & $21.24^{\mathrm{b}} \pm 1.12$ & $16.23^{\mathrm{a}} \pm 1.32$ & $13.63^{\mathrm{a}} \pm 0.85$ & $15.81 \pm 1.99$ \\
\hline 7 & $12.44^{\mathrm{a}} \pm 0.39$ & $21.50^{\mathrm{b}} \pm 1.35$ & $15.35^{\mathrm{a}} \pm 0.87$ & $15.57^{\mathrm{a}} \pm 0.93$ & $16.21 \pm 1.90$ \\
\hline 8 & $12.18^{\mathrm{a}} \pm 0.40$ & $22.50^{c} \pm 1.53$ & $16.54^{\mathrm{b}} \pm 1.47$ & $16.16^{\mathrm{ab}} \pm 0.74$ & $16.85 \pm 2.13$ \\
\hline 9 & $11.31^{\mathrm{a}} \pm 0.79$ & $24.28^{c} \pm 1.57$ & $20.39^{\mathrm{bc}} \pm 1.99$ & $19.89^{b} \pm 1.60$ & $18.97 \pm 2.74$ \\
\hline 10 & $11.33^{\mathrm{a}} \pm 0.57$ & $24.09^{\mathrm{b}} \pm 1.63$ & $21.26^{\mathrm{b}} \pm 2.06$ & $20.60^{b} \pm 1.93$ & $19.32 \pm 2.77$ \\
\hline 11 & $10.21^{\mathrm{a}} \pm 0.63$ & $27.42^{\mathrm{d}} \pm 1.41$ & $24.10^{\mathrm{cd}} \pm 1.37$ & $19.78^{\mathrm{b}} \pm 1.56$ & $20.38 \pm 3.73$ \\
\hline 12 & $10.53^{\mathrm{a}} \pm 0.48$ & $29.60^{\mathrm{d}} \pm 0.99$ & $26.37^{\mathrm{cd}} \pm 1.21$ & $19.95^{\mathrm{b}} \pm 1.43$ & $21.61 \pm 4.20$ \\
\hline Mean & $11.40^{\mathrm{a}} \pm 0.20$ & $20.68^{\mathrm{c}} \pm 1.43$ & $16.99^{\mathrm{bc}} \pm 1.31$ & $15.41^{\mathrm{b}} \pm 1.01$ & \\
\hline
\end{tabular}

Mean within the row bearing different superscript $(a, b, c, d)$ are significantly different $(\mathrm{p}<0.05)$.

and AST (33.21 \pm 0.12$)$ activities in cattle of As contaminated area (Ghentugachi village, Nadia district) compared to uncontaminated zone $(6.51 \pm 0.10$ and $28.23 \pm$ 0.21 ) that might be resulted from As mediated hepatic injury. However, Mishra et al. (2005) reported non significant effect of dietary supplementation of As at $50 \mathrm{ppm}$ on ALT activity in crossbred calves during 90 days of study. The more pronounced adverse effect of As on serum transaminases activities is of significance in view of the involvement of these variables in heme synthesis and hepatic function. In the present experiment, supplementation of vitamin $\mathrm{E}$ was able to reduce activity of these enzymes that might be due to its ability to protect free radicals responsible for oxidative stress and thereby inhibiting the production of ROS. Abbas (2002) also reported the protective effect of vitamin $\mathrm{E}$ in reducing AST and ALT activity to a normal level when injection of vitamin $\mathrm{E}$ at $20 \mathrm{mg}$ and $\mathrm{Se}$ at $0.22 \mathrm{mg} / \mathrm{kg}$ body weight was given in Saibi lambs. In conflict with the result, Vaswani et al. (2010) reported non significant $(\mathrm{p}>0.05)$ effect of vitamin $\mathrm{E}$ supplementation on these enzyme activities during three months of experimental feeding of As. That might be due to lower dose (50 IU/kg DM) of vitamin E.

Overall, there was no effect of dietary treatments on plasma total protein. At the end of the experiment $\mathrm{T}_{1}$ group showed lower $(\mathrm{p}=0.048)$ plasma protein compared to control group. Periodically there was decline trend observed (Figure 1). There was no treatmentxperiod interaction. Vitamin $\mathrm{E}$ in both the doses produced significant effect in improving total protein level at the end of experiment. There was increased trend $(\mathrm{p}<0.05)$ of plasma creatinine level in all As treated groups. Vitamin $\mathrm{E}$ in both the doses produced significant effect $(\mathrm{p}<0.05)$ in improving creatinine level at the end of experiment. There was no treatment $\times$

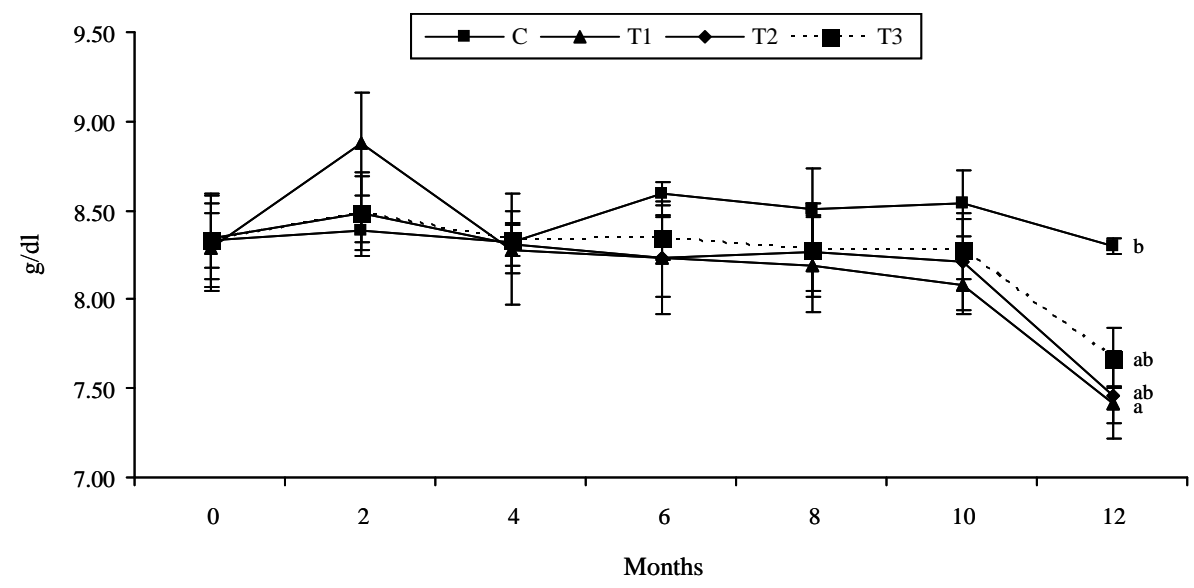

Figure 1. Effect of vitamin E supplementation on plasma total protein $(\mathrm{g} / \mathrm{dl})$ level in As fed goats. Bar indicate means \pm SE. Means followed by the same letter are not significantly different from each other $(\mathrm{p}<0.05)$. 


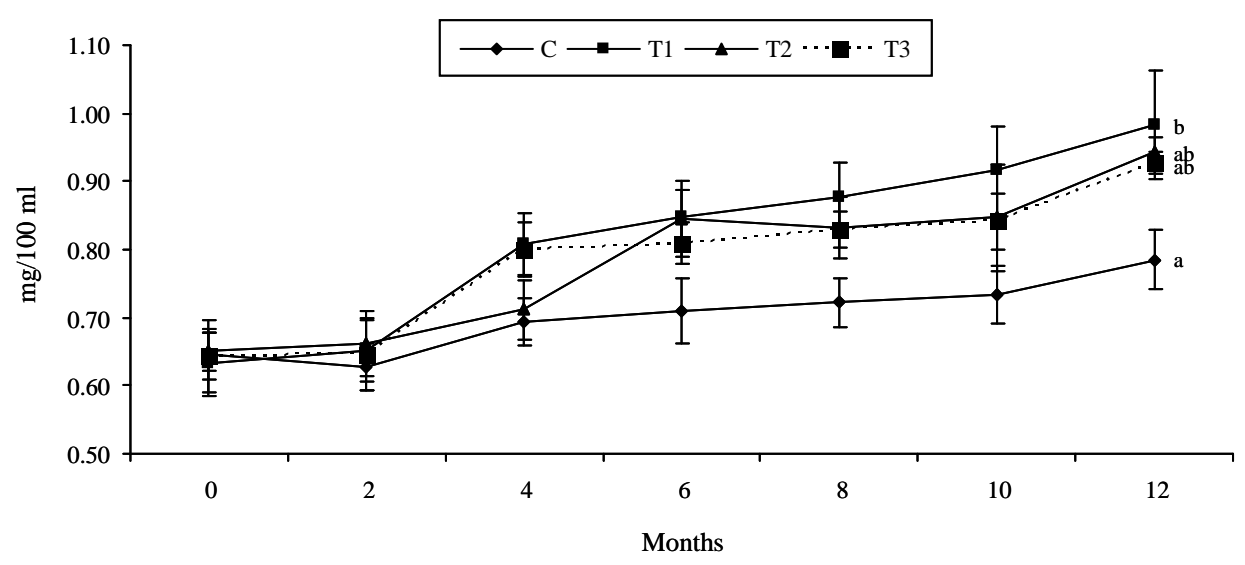

Figure 2. Effect of vitamin E supplementation on plasma creatinine level in As fed goats. Bar indicate means \pm SE. Means followed by the same letter are not significantly different from each other $(\mathrm{p}<0.05)$.

period interaction (Figure 2).

Serum biochemistry profiles are sensitive serological indicator of kidney toxicity. Decreased serum total protein in the trial was similar to the results obtained by Nandi et al. (2005) in rats but in contrast to the report of Uthus (2001) in rats, Biswas et al. (2000) in goats and Wang et al. (2006) in pigs. Hypoproteinaemia in arsenic-induced animals is likely to be due to marked destruction and disintegration of parenchymatous tissues. It is also possible that severe nephrotoxic lesions caused drainage of protein through the urine, resulting to hypoproteinaemia. The elevation of serum protein after vitamin E supplementation was probably due to decreased hepatic insulin resistance allowing insulin to stimulate the incorporation of amino acids into protein (Manning et al., 2004). Increased plasma creatinine was similar to Nandi et al. (2005) but in contrast with Wang et al. (2006). Increased creatinine level indicates initiation of renal infliction due to persistent exposure of As. Blood creatinine is a common test used to evaluate kidney function. So, kidney dysfunction (alteration in glomerular filtration) results in decreased creatinine and blood urea nitrogen clearance and therefore increases their blood levels (Kaneko, 1980). Vitamin E supplementation reduced the As induced increase in creatinine level which may be due to the antioxidant effect of the vitamins.

Critical perusal of the results suggested that As exposure resulted in varying degree of changes in hematobiochemical parameters in lactating goats. Concomitant treatment with vitamins such as $\alpha$-tocopherol reduced As burden as compared to untreated group but the reduction was not sufficient enough to be comparable to that of unexposed controls, thus revealed specific protection of $\alpha$-tocopherol from biochemical damage and thus may be helpful to combat As-associated sufferings in animal.

\section{REFERENCES}

Abbas, S. F. 2002. Effect of vitamin E and selenium injections on lamb viability, growth performance and some blood serum constituents in Saibi lambs. Assiut Vet. Med. J. 47:129-136.

AOAC. 1990. Official methods of analysis. Association of Official Analytical Chemists, $15^{\text {th }}$ Ed. Washington, DC, USA.

Biswas, U., S. Sarkar, M. K. Bhowmik and S. Roy. 1998. Clinicopathological profile of induced chronic arsenic toxicity in goats. Indian J. Anim. Sci. 68:320-323.

Biswas, U., S. Sarkar, M. K. Bhowmik, S. K. Samanta and S. Biswas. 2000. Chronic toxicity of arsenic in goats: clinicobiochemical changes, pathomorphology and tissue residues. Small Rumin. Res. 38:229-235.

Bonses, R. W. and H. H. Taussky. 1945. On the colorimetric determination of creatinine by the Jaffe reaction. J. Biol. Chem. 158:581-591.

Drabkin, D. L. 1944. Photometry and spectrometry: Medical physics, Vol. 1, Year book medical publishers. Inc., Chicago, USA.

Garcia-Shavez, E., I. Jimenez, B. Segura and L. M. D. Razo. 2006. Lipid peroxidative damage and distribution of inorganic and its metabolite in the rat nervous system after arsenite exposure: influence of alpha tocopherol. Neurotoxicology 27:1024-1031.

Hardman, G. and L. E. Limbird. 1996. Goodman and Gilman's The Pharmacological Basis of Therapeutics. 9th edn, McGrawHill Companies, New York, pp. 633-634.

Healy, S. M. and A. V. Aposhian. 1999. Diversity of inorganic arsenite transformation. Biol. Trace Elem. Res. 60:249-266.

Hughes, M. F. 2002. Arsenic toxicity and potential mechanisms of action. Toxicol. Lett. 133:1-16.

Ianchev, I. 2001. Influence of some geo-chemical ecological factors on some blood hematological characteristics in sheep from Chiprovitei. Zhivotnovu d.-Nauki. 38:41-43.

Kaneko, J. J. 1980. Clinical biochemistry of domestic animals. 3rd Edn. Academic press, NY, USA.

Koller, A. 1984. Proteins. In: Clinical Chemistry: theory, analysis and correlation (Ed. L. A. Kaplan and A. J. Pesce). C.V.Mosby, Toranto, Canada. pp. 1268-1327.

Liu, S. X., M. Athar, I. Lippai, C. Waldren and T. K. Hei. 2001. Induction of oxy-radicals by arsenic: implication for mechanism of genotoxicity. Proc. Natl Acad. Sci. 98:16431648.

Manning, P. J., W. H. F. Suther and R. J. Walker. 2004. Effect of high dose vitamin $\mathrm{E}$ on insulin resistance and associated 
parameters in overweight subjects. Diabetes Care 27:2166.

Mishra, C. S., V. Mani and H. Kaur. 2005. Effect of arsenic on immunity, oxidative enzyme and various haematological parameters in crossbred calves. Asian-Aust. J. Anim. Sci. 18:497-501.

Morand-Fehr, P. 1981. In "Goat Production" (Ed. G. Gall). pp 193-232. Academic Press, NY, USA.

Nandi, D., R. C. Patra and D. Swarup. 2005. Effect of cysteine, methionine, ascorbic acid and thiamine on arsenic induced oxidative stress and biochemical alterations in rats. Toxicology 211:26-35.

Nandi, D., R. C. Patra and D. Swarup. 2006. Oxidative stress indices and plasma biochemical parameters during oral exposure to arsenic in rats. Food Chem. Toxicol. 44:1579-1584.

NRC. 1981. Nutrient requirements of goats: angora, dairy and meat goats in temperate and tropical countries. National Academy Press, Washington DC, USA.

Pandey, P. K., M. Roy and S. Roy. 2005. Clinico-haematological and biochemical alterations in acute arsenic toxicity in goats. Indian J. Vet. Med. 25:57-60.

Patel, A. K., N. Kewalramani, V. Mani and H. Kaur. 2009. Effect of vitamin E supplementation in growing kids fed on arsenic containing diet. Indian J. Anim. Nutr. 26:9-16.

Rabbani, G. H., S. K. Saha, A. Mastura and M. Farzana. 2003. Antioxidants in detoxification of arsenic induced oxidative injury in rabbits. J. Environ. Sci. Health A 38:273-287.

Ramanathan, K., B. S. Balakumar and C. Paneerselvam. 2002. Effects of ascorbic acid and $\alpha$-tocopherol on arsenic-induced oxidative stress. Hum. Exp. Toxicol. 21:675-680.
Rana, T., A. K. Bera, S. Das, D. Bhattacharya, S. Bandyopadhyay, D. Pan and S. K. Das. 2010. Effect of chronic intake of arsenic-contaminated water on blood oxidative stress indices in cattle in an arsenic-affected zone. Ecotoxicol. Environ. Saf. 73:1327-1332.

Rana, T., S. Sarkar, T. Mandal and S. Batabyal. 2008. Hematobiochemical profiles of affected cattle at arsenic prone zone in Haringhata block of Nadia District of West Bengal in India. Inter. J. Hematol. 4:2.

Reitman, S. and S. Frankel. 1957. Colorimetric method for the determination of SGOT and SGPT. Am. J. Clin. Pathol. 33:97.

Santra, A., J. Das Gupta, B. K. De, B. Roy and D. N. Guha Mazumer. 1999. Hepatic manifestations in chronic arsenic toxicity. Indian J. Gastroenterol. 18:152-155.

Uthus, E. O. 2001. High dietary arsenic exacerbates copper deprivation in rats. J. Trace Elem. Exp. Med. 14:43-55.

Vaswani, S., V. Mani, N. Kewalramani and H. Kaur. 2010. Mitigation of adverse effects of arsenic by supplementing vitamin $\mathrm{E}$ in crossbred kids maintained at low protein diet. Indian J. Anim. Nutr. 27:347-354.

Wang, L., Z. R. Xu, X. Y. Jia and X. Y. Han. 2006. Effects of dietary arsenic levels on serum parameters and trace mineral retentions in growing and finishing pigs. Biol. Trace Elem. Res. 113:155-164.

Woods, J. S. and B. A. Fowler. 1986. Alteration of hepatocellular structure and function by thallium chloride: Ultra structural, morphometric, and biochemical studies. Toxicol. Applied Pharmacol. 83:218-229. 